\title{
LIQUEFACTION AT KAIAPOI IN THE 1901 CHEVIOT, NEW ZEALAND, EARTHQUAKE
}

\author{
J.B. Berrill', P.C. Mulqueen², E.T.C. $\mathrm{Ooi}^{3}$
}

\begin{abstract}
Seismic liquefaction occurred in northeast Kaiapoi during the 1901 Cheviot earthquake. A contemporary newspaper report describes the ejection of sand and lateral spreading in Waites' market garden at the east end of Sewell Street, Kaiapoi and also south of the Waimakariri River near Belfast.
\end{abstract}

Piezocone probing and rotary drilling on the Waites property in Sewell Street and at three other sites in northeast Kaiapoi found loose, fine sands and silty sands with cone resistance $\mathrm{q}_{\mathrm{c}}$ as low as 2 to $3 \mathrm{MPa}$; it is not surprising that liquefaction was observed in 1901.

Lack of precise seismological parameters for the 1901 earthquake precludes any definite conclusions about the performance of liquefaction potential models. However, the occurrence of liquefaction strongly suggests that the M6.5 magnitude estimated by Dibble et al. [1980] is too small, and that local magnitude in 1901 was larger than the surface-wave value of about 6.9 of Dowrick and Smith [1990]. A value in the range of 7.1 to 7.5 seems more likely.

Comparison of Dutch cone penetrometer resistances and standard penetration test $\mathrm{N}$-values supports the old $\mathrm{q}_{\mathrm{c}}$ (bars)/N=4 rule. Because of the large amount of scatter, use of the more refined rule of Robertson of Campanella, where $q_{c} / N$ is a function of $D_{50}$, does not seem justified.

The penetration testing results confirm that there is a significant risk of liquefaction at Kaiapoi. Furthermore, we now have four reference sites, each with slightly different soil conditions, whose performance can be monitored following future earthquakes in the region.

\section{INTRODUCTION}

The 1901 Cheviot earthquake is one of the strongest earthquakes to occur in the Canterbury province of the South Island of New Zealand since European settlement. Its magnitude has been estimated at around 6.5 to 7 by Dibble et al. [1980] and as $M_{s}$ $=6.9 \pm 0.2$ by Dowrick and Smith [1990]. McKay [1902] records reports of ejected sand and water, and he himself observed fissures, in the epicentral region that were almost certainly sand boils and the results of lateral spreading due to liquefaction. Sand boils and other liquefaction phenomena were observed also at a number of other locations to the south of the epicentre [Fairless and Berrill, 1984]. The most widely reported cases of liquefaction occurred in the town of Kaiapoi, about $90 \mathrm{~km}$ south of the estimated epicentre. There is also a rather vague newspaper reference to liquefaction near Belfast, some $6 \mathrm{~km}$ further from the epicentre to the south of Kaiapoi, which is the most distant report we have been able to find.

1 Department of Civil Engineering, University of Canterbury (Fellow)

2 Kingston Morrison, Consulting Engineers, Wellington, New Zealand (Member)

3 Former graduate student, University of Canterbury
The aim of this article is to document the historical reports of liquefaction at Kaiapoi in 1901 and to describe soil conditions at the site, determined by rotary boring and penetrometer tests.

Kaiapoi, with a population of about 7000 , is situated on the Kaiapoi River, near the north eastern end of the Canterbury Plains, about $20 \mathrm{~km}$ north of the city of Christchurch (Figure 1). The plains themselves are formed by large coalescing alluvial fans extending some $50 \mathrm{~km}$ from the Southern Alps to the west. At Kaiapoi, $300-400 \mathrm{~m}$ of late Pleistocene sand and gravel overlies early Pleistocene, Tertiary and Cretaceous rock, that in turn overlies greywacke basement rock at a depth of more than $2 \mathrm{~km}$. Sea level fluctuations during glacial periods have led to interbedded marine and terrestrial sediments in the upper one hundred metres or so [Brown \& Webber, 1992].

The dominant, present-day feature of the Kaiapoi area is the Waimakariri River (Figures 1 and 2). Before 1868, the Waimakariri River comprised two principal branches: a north branch flowing in the channel of the present Kaiapoi River, and a south branch flowing in the now abandoned channel seen in Figure 2 running northeast from the lower left hand side of the photograph, to meet the north branch at the bend in the Kaiapoi River near the centre of the photograph at the foot of Charles Street [Reid et al., 1982]. From 1868, the Waimakariri River near Kaiapoi has followed its present course in a cut channel constrained by stopbanks. Prior to 1868 , the Waimakariri was 


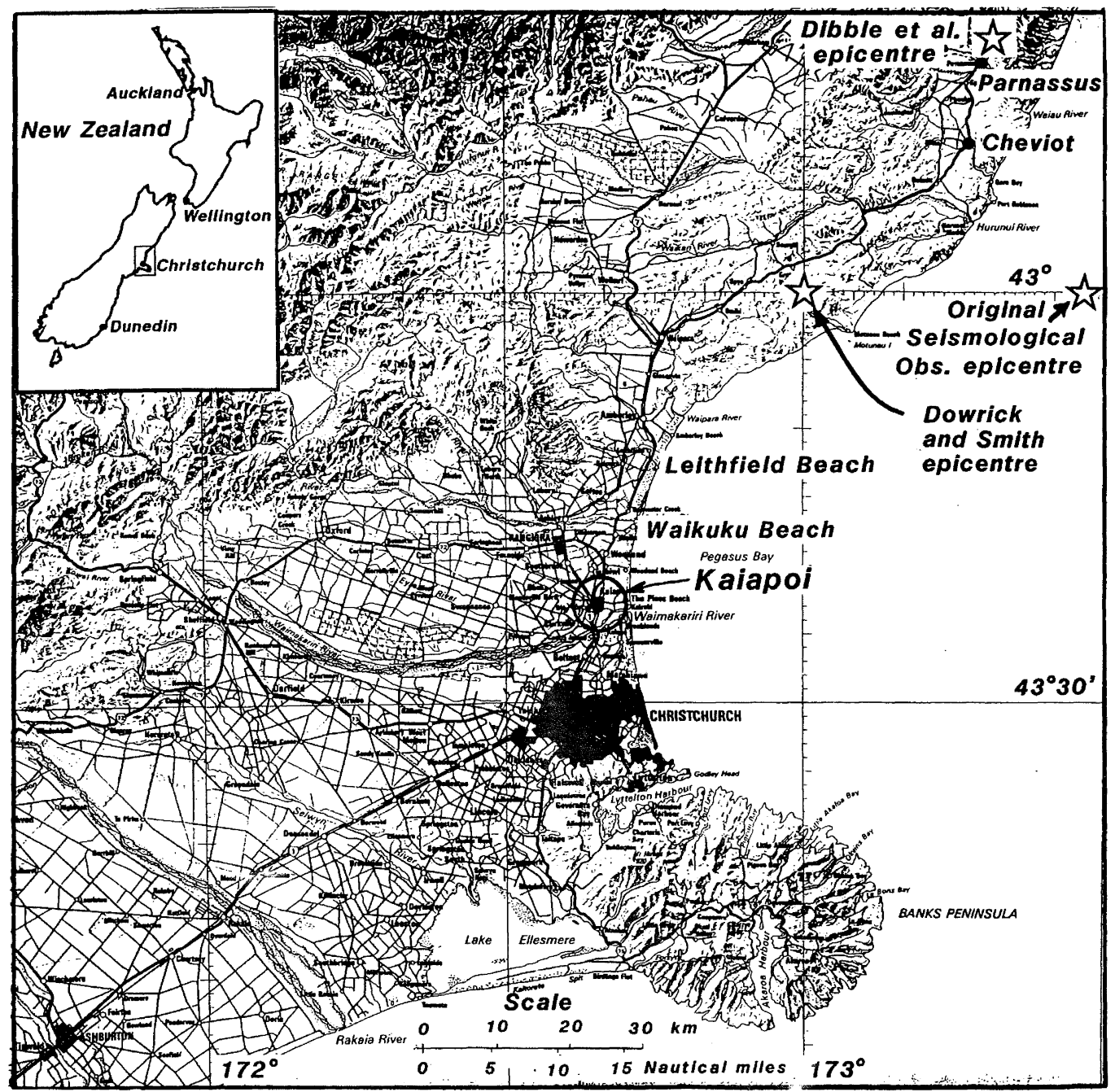

FIGURE 1 The North Canterbury region of the South Island of New Zealand, showing the location of Kaiapoi and estimated 1901 earthquake epicentres.

free to meander, and several old meander loops are seen in Figure 2. In particular, the semicircular feature to the north of the Kaiapoi River near the centre of the photograph marks a large, recent meander in which loose silt and sands would have been deposited. Furthermore, the site is behind the present dune system, and the very loose, silty nature of the surficial soils found in the investigation suggests that they may be at least partly estuarine in origin.

In the 150 years since the beginning of European settlement, eight earthquakes, listed in Table 1, have produced intensities of MM 7 or greater in nearby Christchurch [Dibble et al., 1980]. Newspapers and Christchurch City Council records, particularly those of the former Christchurch Drainage Board, were searched for reports of liquefaction in the North Canterbury region, especially in Christchurch itself. Apart from damage to sewers in two locations (the East Belt sewer of St Asaph St and the Ferry Road sewer at its outlet) in the 1888 Amuri earthquake, no report of liquefaction damage in the Christchurch urban area could be found in these earthquakes.

The clearest report of liquefaction in historical earthquakes in the region comes from Kaiapoi in the 1901 Cheviot earthquake. There are also reports of apparently minor occurrences of liquefaction at Waikuku and Leithfield beaches in the 1922 earthquake [Dibble et al., 1980].

\section{OBSERVATIONS IN 1901}

From newspaper reports, it is clear that liquefaction occurred over an area of about two or three town blocks at the eastern end of Sewell and Charles Streets on the north bank of the Kaiapoi River (Figures 2, 4). The area affected probably extended east to the Waimakariri River. A vivid report of ground effects observed here is found on page 6 of the Christchurch newspaper, "The Press", of November 18, 1901. Ejection of sand, lateral spreading and ground settlement are described. The passage reads:

\section{"REMARKABLE FISSURES IN THE EARTH"}

"At Kaiapoi, when the shock had passed, Mr W. Waites, who owns an orchard and garden at the end of Charles and Sewell Streets, noticed that his land was apparently flooding from springs having been opened. It was then discovered that across his land, and part of Mr Dunn's section, and over the surface of a paddock of several acres held by Mr J. Sims, fissures from 


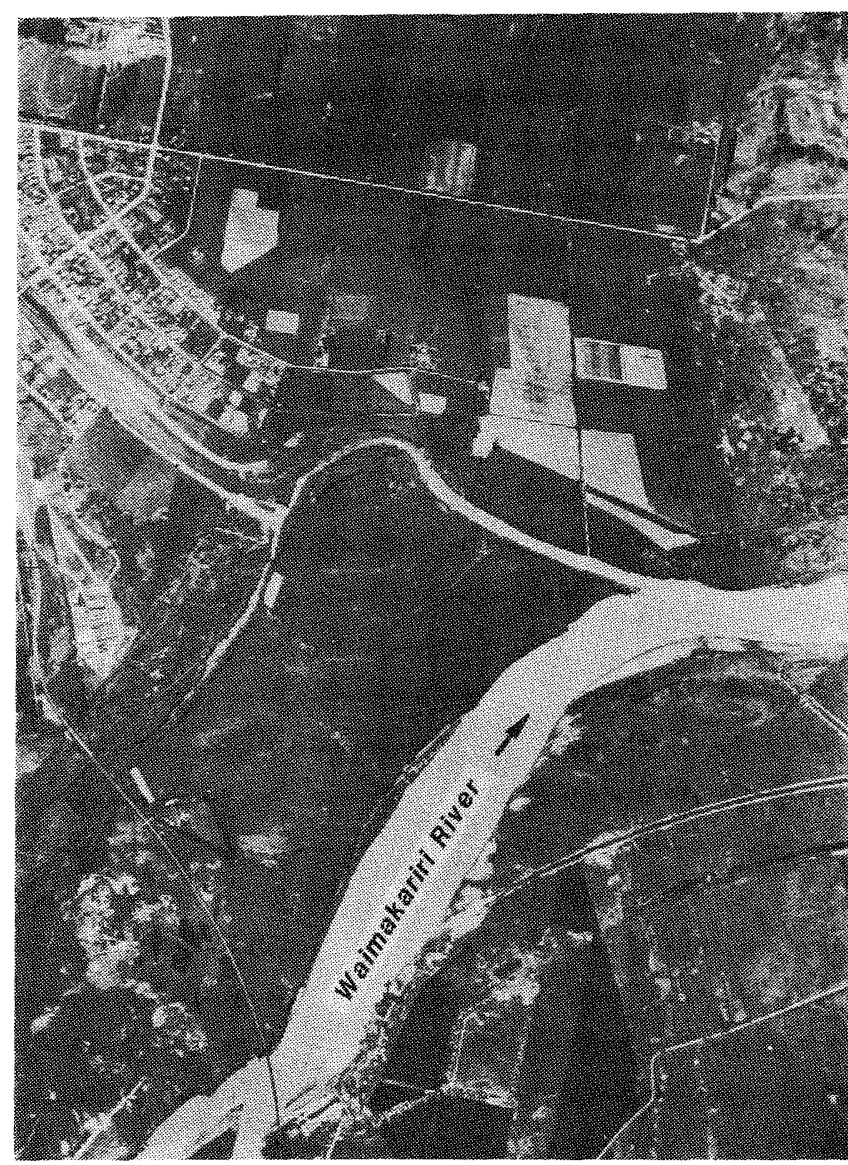

FIGURE 2 A 1941 aerial photograph of north east Kaiapoi. The Kaiapoi River flows into the Waimakariri River, seen in the lower right of the photograph. Note the semi-circular feature north of Cass Street near the centre of the photo, denoting a former meander loop of the Waimakariri. Several other, less prominent, meanders are seen in this photograph. (Photo: NZ Aerial Mapping)

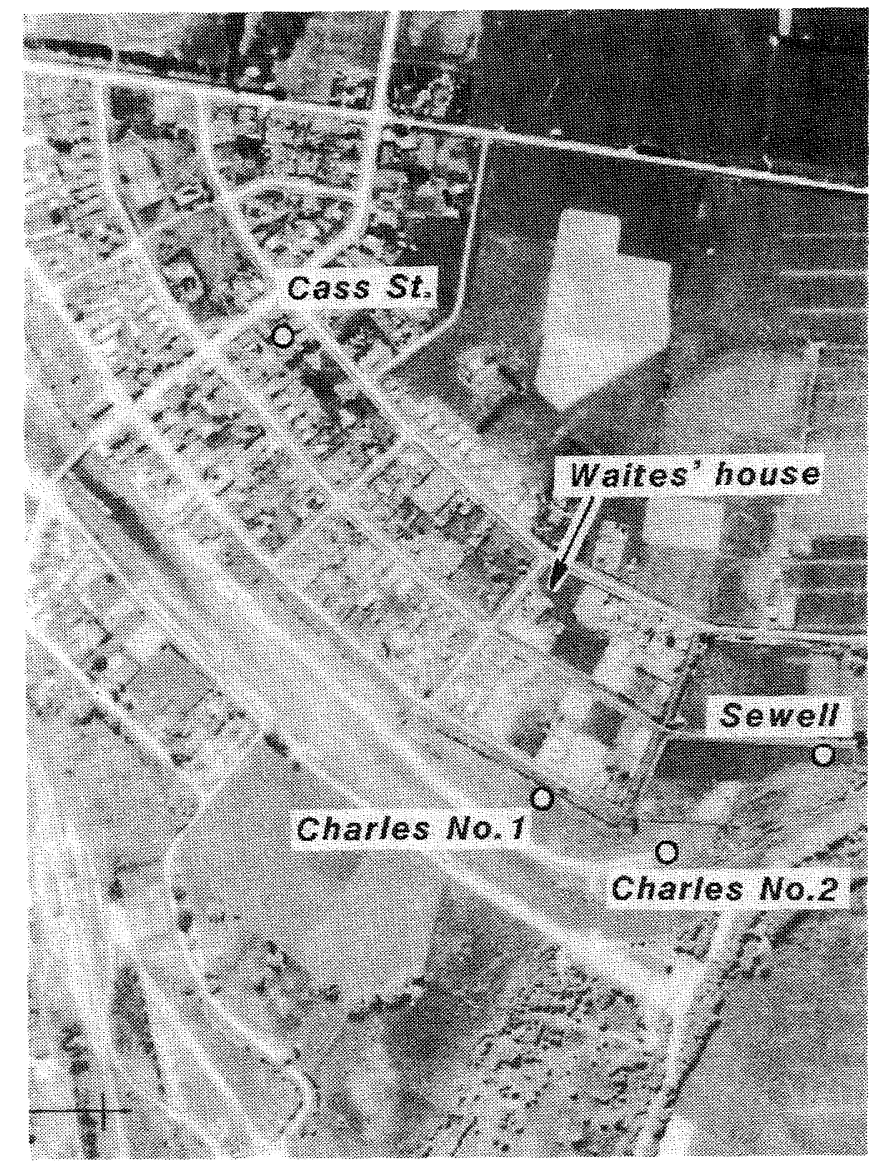

FIGURE 3 An enlargement of the area studied, from the 1941 photograph, showing Waites' house surrounded by part of his market garden, and the test sites.

Table 1. Historical earthquakes producing an MM intensity of seven or more at Christchurch (from Dibble et al. 1980). Two sets of values are shown: those from the Seismological Observatory files, Wellington and those reassessed by Dibble et al. in 1980 .

\begin{tabular}{|c|c|c|c|c|c|c|}
\hline \multirow{2}{*}{ Earthquakes } & \multicolumn{3}{|c|}{ Seismological Observatory Files } & \multicolumn{3}{|c|}{ Dibble $e t$ al. } \\
\hline & $\begin{array}{l}\text { Epicent. } \\
\text { dist. } \mathbf{k m}\end{array}$ & $\begin{array}{c}\text { MM at } \\
\text { Christchurch }\end{array}$ & $\mathbf{M}_{\mathbf{L}}$ & $\begin{array}{l}\text { Epicent. } \\
\text { dist. } \mathbf{k m}\end{array}$ & $\begin{array}{c}\text { MM at } \\
\text { Christchurch }\end{array}$ & $\mathbf{M}_{\mathbf{L}}$ \\
\hline 1869,5 Jan & 60 & $7-8$ & 4.5-6 & 10 & $7-8$ & 5.75 \\
\hline 1870,31 Aug & 60 & 6 & $4.5-6$ & 50 & $6-7$ & 6.5 \\
\hline $1881,5 \mathrm{Dec}$ & 78 & $7-8$ & $6-7.5$ & 80 & $6-7$ & 6.25 \\
\hline 1888,1 Sept & 78 & $7-8$ & 7 & 105 & 7 & 6.75 \\
\hline 190116 Nov & 92 & 6 & 6-7.5 & 110 & 7 & 6.5 \\
\hline $1922,25 \mathrm{Dec}$ & 66 & 6 & $6-7.5$ & 66 & 7 & 6.75 \\
\hline $1929,9 \mathrm{Mar}$ & 125 & 6 & 6.9 & 125 & $6-7$ & 6.9 \\
\hline 1929,17 Jun & 195 & 6 & 7.7 & 195 & 7 & 7.7 \\
\hline
\end{tabular}




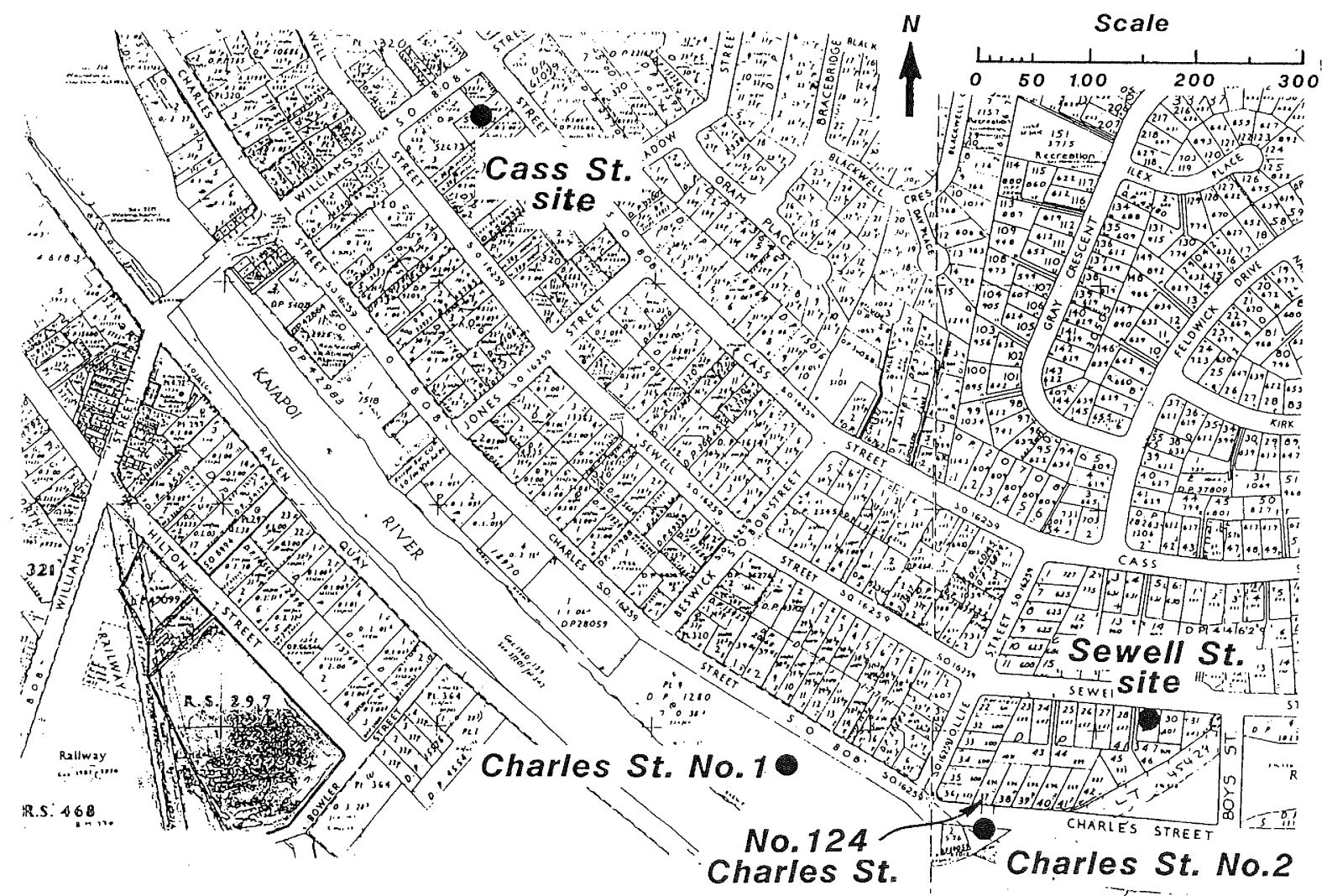

FIGURE 4 Street plan of Kaiapoi, showing the test sites.

Iin to Bin in width, and several chains in length, had opened. These extended across Sewell Street, and affected an embankment. From these earthquake openings the water was freely issuing in such volume as to cause apprehensions of a probable inundation. Fortunately the rapid exudation of water seemed to be checked by a liberal supply of sand from a grey quicksand layer below the level of the river, and this was deposited in the orchard and elsewhere in the shape of round and oval porridge pots and little hills. The water, which had risen about six inches in an hour or two, disappeared by percolation, leaving the sand deposits in fantastic forms.

The fissures remained open, and could be probed to a depth of six feet. On Mr Waites' section the artesian well pipe had been raised a foot out of the ground, and the elevation of part of his land he maintains has been raised to a higher level. The flow of an artesian well, 200ft in depth, was increased, while the flows of three other tube wells to the first strata were entirely suspended. Wells in other parts of Kaiapoi also went dry. Upon Mr W.J. Dunn's land an upheaval was also noticed; and $\mathrm{Mr}$ Dunn's pump and tube well in the wash-house was raised bodily 4 inches.

Similar openings were subsequently found further to the eastward. The direction of the fissures was S.W. and N.E., and some of them in two hours were observed to visibly close. The widest was in Mr Waites' garden, and as it intercepted a waterrace the water disappeared into the ground.

On the opposite side of the Waimakariri to Mr Waites' land a crack is traceable out of the river $2 f t$ in width on to the river bed at the end of Mr James Holland's farm, where one of the fissures is 9in wide, and has, like many smaller cracks of the earth, been filled with quicksand blowing up, as in the other cases referred to. Mr J. Holland. jun., followed up the fissures on the south side of the river for several chains, until they disappeared with the loose earth and sand. In continuation of the cracks referred to, a similar one was traced across the North road near Belfast. The rents referred to seemed to be within a comparatively narrow strip, about half a chain wide. But for the quicksand from several feet below the surface blowing up into the rents they would have remained open. A rod several feet long was inserted in the sand, but was not long enough to test the exact depth of the ooze, though it is surmised to have come up from $20 f t$ to $25 f t$. Some persons were inclined to believe the springs might be of a thermal character, but they had only a smell of swamp gas, and not the least trace of sodium to give them any virtue. Crowds visited the places indicated on Saturday (16/11/01) and yesterday, but the neatly formed mounds of sand thrown up had been disfigured by children on Saturday. Numbers of samples of the sand were taken away."

This is ample evidence that liquefaction had occurred in the Charles Street, Sewell Street area.

An aerial photograph (Figure 2) taken in 1941 shows Charles St ending at Jollie St, but Sewell St continuing east to the presentday Commercial St (see Street Map in Figure 4). Mr Waites himself and his market garden are well remembered by elderly Kaiapoi residents. His house, at 14 Beswick St, is marked on the photo in Figure 3. It is thought that in 1901 his gardens and orchards occupied the block of his house, bounded by Cass, Sewell, Beswick and Jollie Streets and the block diagonally southeast, running east from Jollie St, between Sewell and Charles Streets. We have been unable to pinpoint the Sims and Dunn properties referred to in the newspaper report. 


\section{SOIL INVESTIGATIONS, 1986-1989}

Since the aerial photograph shown in Figure 2 was taken in 1941, Kaiapoi has grown to the north east. One of the few vacant blocks of land in the original Waites market garden was found at 125 Sewell St, east of Jollie St. Dutch cone (CPTU) probes, using both Parez and Fugro piezecones, were carried out at this site and at three other sites east of Williams St and north of the Kaiapoi River (Figure 4).

The first tests were made at the Sewell St site in 1986, using a $45 \mathrm{~mm}$ Parez cone [Ooi, 1987]. They showed a layer of loose sand $\left(\mathrm{q}_{\mathrm{c}} \leq 5 \mathrm{MPa}, \mathrm{R}_{\mathrm{f}} \leq 0.5 \%\right)$ between 2 to $6 \mathrm{~m}$ with a high liquefaction potential. In 1988, a Fugro piezocone was used to investigate three other sites along the north bank of Kaiapoi River to gauge the extent of the liquefiable soils [Mulqueen, 1989]. Further CPTU probes with both cones were carried out in 1989 principally to test different filter positions and de-airing techniques for the pore pressure transducer. Rotary borings were made at the two Charles St sites in order to carry out standard penetration tests (SPTs) and to retrieve samples.

Table 2 lists the piezocone tests carried out, together with details of the cone configurations. None of the tests was perfect. In general, the points performed well on both cones, and the $\mathrm{q}_{\mathrm{c}}$ plots are reliable. However, the load cell on the sleeve of the Parez cone was faulty, so no friction ratio traces are shown in its results. However, it has a very sensitive pore pressure transducer, and its pore pressure system is easy to saturate. Hence, it yielded good pore pressure traces. While the Fugro cone gave reliable cone and sleeve results, its pore pressure measurement system was more difficult to saturate, and pore pressure measurements taken at Kaiapoi from this cone are unreliable in all but very permeable soils.

\section{Sewell Street}

Figure 5 shows the results of the four tests at 125 Sewell St (Figure 4) plotted together. (Plots of the individual cone logs are given in the report by Berrill et al., 1994). Unreliable friction ratio traces from the Parez cone and some pore pressure traces from the Fugro cone have been omitted. The probes start below the water table in pre-bored holes, to maintain saturation of the pore pressure transducer system.

The composite plot shows three broad strata: a layer of sandy silt to a depth of around $1.8 \mathrm{~m}$; loose silty sand from about $1.8 \mathrm{~m}$ to $3.5 \mathrm{~m}$; medium dense silty sand from $3.5 \mathrm{~m}$ down to a much denser cohesionless material at around 6.5 to $7 \mathrm{~m}$. In the absence of drillhole samples, the chart of Robertson, Campanella and Wightman [1983] has been used to infer these soil classifications. Within these layers, there are fluctuations in $\mathrm{q}_{\mathrm{c}}$, probably reflecting sublayers; but the fairly uniform and small value of $R_{f}$ indicates that the material is predominantly

Table 2. Piezocone Tests at Kaiapoi, 1986-1989

\begin{tabular}{||l|l|l|l|l|l|l||}
\hline \hline Site & $\begin{array}{l}\text { Test } \\
\text { No }\end{array}$ & Code & Date & Cone & $\begin{array}{l}\text { Filter } \\
\text { Position }\end{array}$ & $\begin{array}{l}\text { WT } \\
\text { (m) }\end{array}$ \\
\hline 125 Sewell St & 1 & KAI004 & 12 Nov 86 & P & S & \\
& 2 & KAI010 & 12 Nov 86 & P & S & 0.89 \\
& 3 & KAI005 & 15 Nov 88 & F & S & 1.2 \\
& 4 & KAI005 & 16 Nov 88 & F & S & 1.12 \\
\hline Charles St, No 1 Site & 5 & KAI001 & 10 Nov 88 & F & S & 2.05 \\
(Approx 30 m from & 6 & KAP005 & 8 Feb 89 & P & S & 2.02 \\
kerb opposite 114 Charles Street) & 7 & KAP016 & 8 Feb 89 & P & C & 2.10 \\
\hline Charles St No 2 Site (opposite 126 & 8 & KAI002 & 10 Nov 88 & F & S & 2.0 \\
Charles Street) & 9 & KAI003 & 15 Nov 88 & F & S & 2.0 \\
\hline 19 Cass Street (near Williams & 10 & KAP002 & 26 Jan 89 & P & S & 1.97 \\
Street) & 11 & KAP003 & 26 Jan 89 & F & S & 2.0 \\
& 12 & KAP004 & 26 Jan 89 & P & C & 1.94 \\
& 13 & KAI301 & 31 May 89 & F & S & 1.46 \\
& 14 & KAI302 & 31 May 89 & P & S & 1.55 \\
& 15 & KAI303 & 31 May 89 & F & S** & 1.45 \\
& 16 & KAI004A & 15 Nov 88 & F & S & 1.6 \\
& 17 & KAP001 & 17 Jan 89 & P & S? & 1.65 \\
\hline
\end{tabular}

* $\mathrm{P}=$ Parez cone $\mathrm{S}=$ filter on shoulder between cone and sleeve

$\mathrm{F}=$ Fugro cone $\mathrm{C}=$ filter on cone

** Coarse plastic filter 

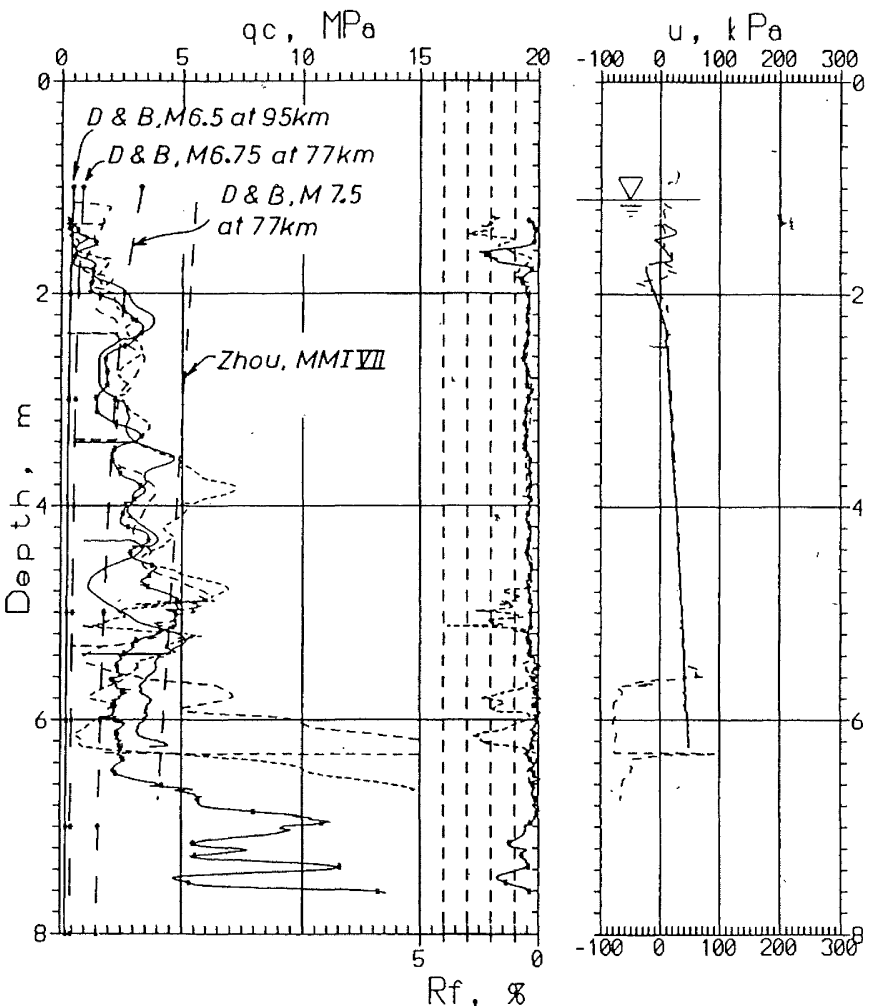

FIGURE 5 Combined piezocone results for 125 Sewell St. together with threshold values of $q_{c}$ from the Zhou [1980] and the Davis and Berrill [1983] model for various seismic parameters. The water table is assumed to be at $1.0 \mathrm{~m}$ in plotting the threshold curves.

cohesionless. It is interesting to note the newspaper remark that the 1901 cracks could be probed to a depth of 6 feet. This depth coincides well with the silt-sand interface at this site.

Using the criterion of Zhou [1980], the liquefaction threshold value of $\mathrm{q}_{\mathrm{c}}$ has been plotted for the MM 7 intensity of ground shaking observed at Kaiapoi in 1901. We see that according to this criterion, almost the entire profile is expected to liquify, especially the loose layers above $3.5 \mathrm{~m}$. This is consistent with the ground cracking and ejection of sand that was observed in this area in 1901, though, to some extent, this argument may be circular. since the occurrence of liquefaction at Kaiapoi was one of the indicators used by Dibble et al. [1980] in assigning the value of MM 7. However, in the absence of precise seismological parameters there is little alternative to using Intensity and the Zhou criterion.

\section{Cass Street}

A second set of piezocone probes was carried out at 19 Cass St, near the intersection of Cass and Williams Streets, about $800 \mathrm{~m}$ northwest of the Sewell St site. This site was chosen to have a better geographical coverage of soil conditions in NE Kaiapoi rather than because of any report of liquefaction at the site. We could find no report to confirm or deny liquefaction at this site in 1901. The probes were made in two clusters on this section, about $20 \mathrm{~m}$ apart, as shown in Figure 6. We will focus on the southern group of 7 probes, numbers 9 to 15 . Results from these tests are plotted together in Figure 7.

The seven probes of the southern group cover an area of ground roughly $10 \mathrm{~m}$ in diameter and represent trials with the two different cones, with different filter positions for the pore
CASS ST

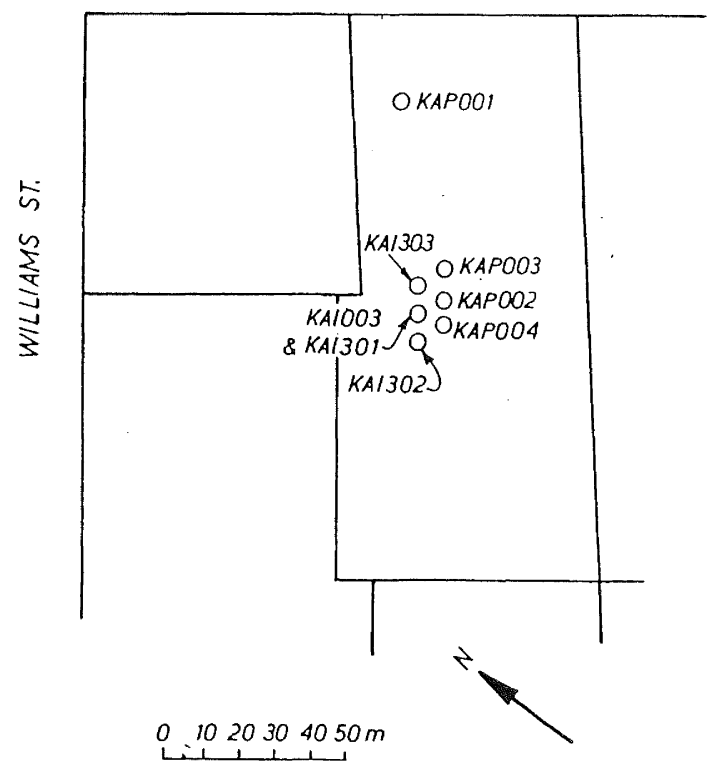

FIGURE 6 Probe positions, 19 Cass St.

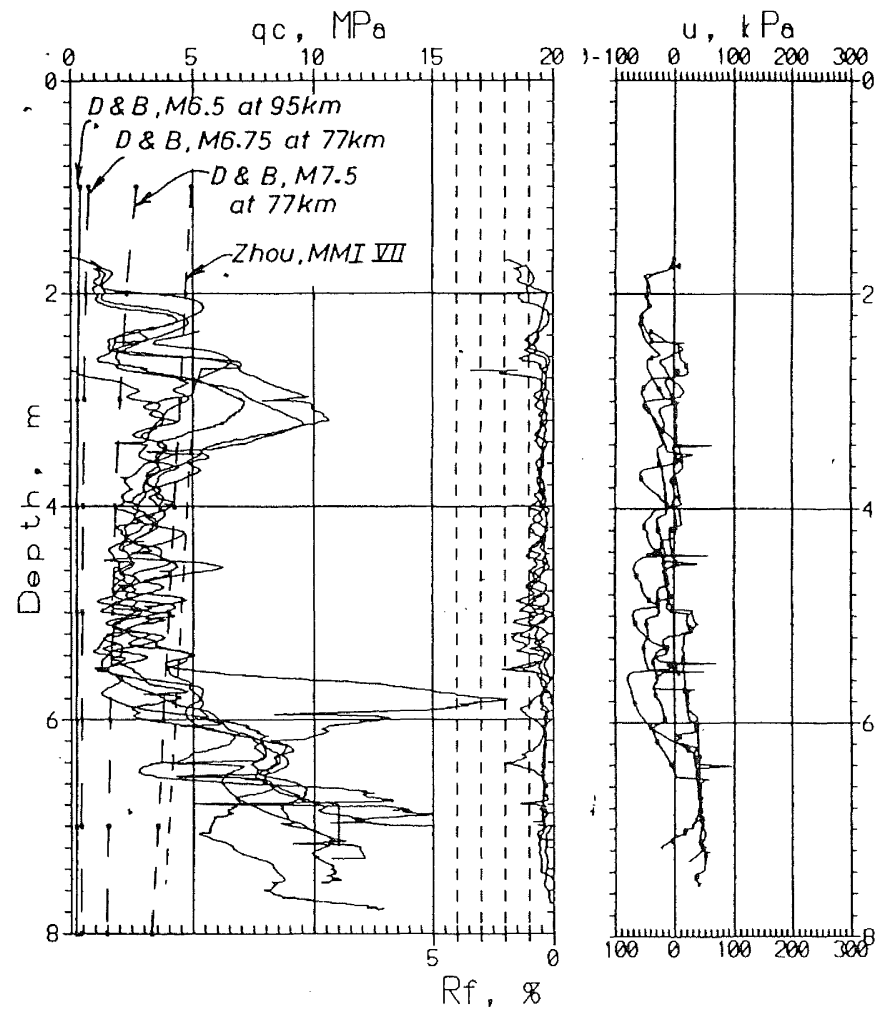

FIGURE 7 Combined piezocone results for 19 Cass St. together with predicted threshold values. Water table assumed at $2.0 \mathrm{~m}$.

pressure transducer and different de-airing techniques in the case of the Fugro cone.

The marked differences between the various pore pressure traces indicate the importance of good de-airing and of a standard filter position, as well as reflecting inhomogeneities in the soil itself. The $\mathrm{q}_{\mathrm{c}}$ traces are generally similar, and variations between probes are most probably due to variations in soil properties. A similar remark applies to the $R_{f}$ traces. 
The low friction ratio, $R_{f}$, indicates a cohesionless material throughout, again with three broad strata: a silty sand of variable density to about $3.5 \mathrm{~m}$; a more uniform loose silty sand from 3.5 to near $6 \mathrm{~m}$; a more dense, cleaner sand below about 5.5 to $6 \mathrm{~m}$.

The cone resistance of the silty sand stratum between 3.5 and $6 \mathrm{~m}$ falls below the critical value of Zhou for the $1901 \mathrm{MM} 7$ intensity of shaking, and it is possible that liquefaction occurred beneath this site, too, though because of its greater distance from the river, marked lateral spreading cracks may not have appeared. However, as discussed below, the Zhou model is imprecise and perhaps quite conservative, so the performance of this site in 1901 remains uncertain.

\section{River Bank Reserve, Charles Street No 1 Site}

Results from a set of three probes carried out on the River Bank Reserve opposite 114 Charles St are shown in Figure 8 . A detailed location plan is given in Figure 9. Both Charles St sites have been filled and regraded from their original condition. This should have increased their liquefaction resistance from their 1901 state, through an increase in overburden stress, and through consolidation.

A rotary boring with standard penetration tests (SPT) was carried out at this site (Figure 10). The piezocone results are generally consistent with those from the boring. For example, the transition at about $2.6 \mathrm{~m}$ from loose silty fine sand to grey fine sand occurs within the range of the first SPT starting at $2.4 \mathrm{~m}$. This recorded $400 \mathrm{~mm}$ of set for a seating blow, followed respectively by 2 and 4 blows per $150 \mathrm{~mm}$. This corresponds to the marked reduction in friction ratio that we see at $2.5 \mathrm{~m}$ in the piezocone probe plots, together with a steady increase in $\mathrm{q}_{\mathrm{c}}$.
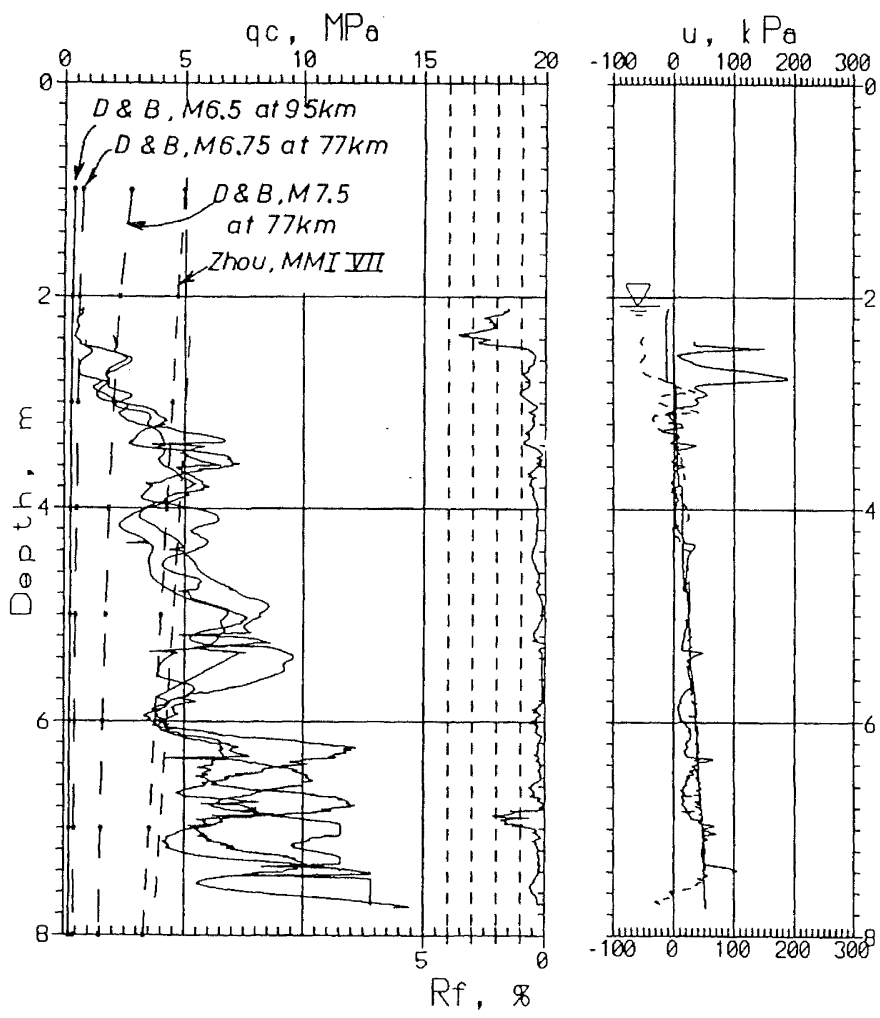

FIGURE 8 Combined piezocone results for the Charles $S t$ No 1 site, opposite 114 Charles St. Watertable assumed at $2.0 \mathrm{~m}$.

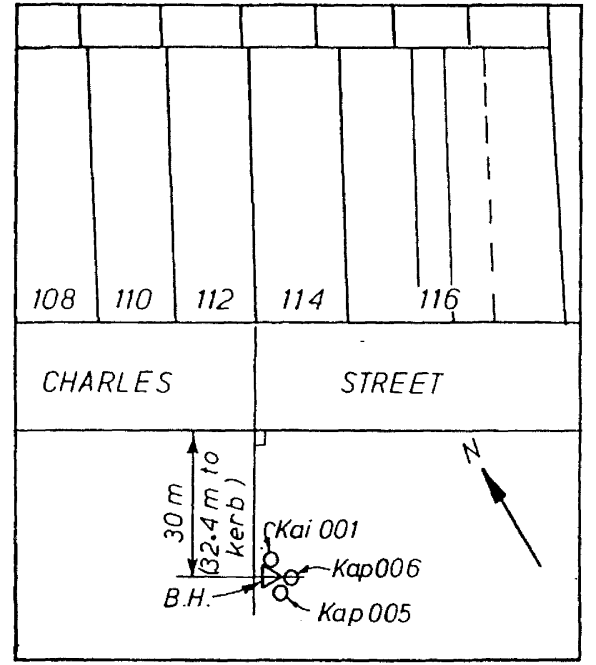

FIGURE 9 Probe positions, Charles St No 1 site.

At this site, the most likely candidate for liquefaction is the layer of loose fine sand from 2.5 to about $3.3 \mathrm{~m}$. Its $\mathrm{q}_{\mathrm{c}}$ value falls well below Zhou's criteria shown by the dotted line in Figure 8, and it is very likely that this area liquefied in 1901.

\section{River Bank Reserve, Charles Street No 2 Site}

One Fugro piezocone probe (Figure 11), and one rotary boring (Figure 12), were carried out on the River Bank Reserve to the south of the road, opposite number 126 Charles Street. Here, the loose fine sand layer between about 3 and $4.5 \mathrm{~m}$ is a candidate for liquefaction in MM 7 shaking, together with thinner layers around $5.5 \mathrm{~m}, 7.5 \mathrm{~m}$ and $9.0 \mathrm{~m}$.
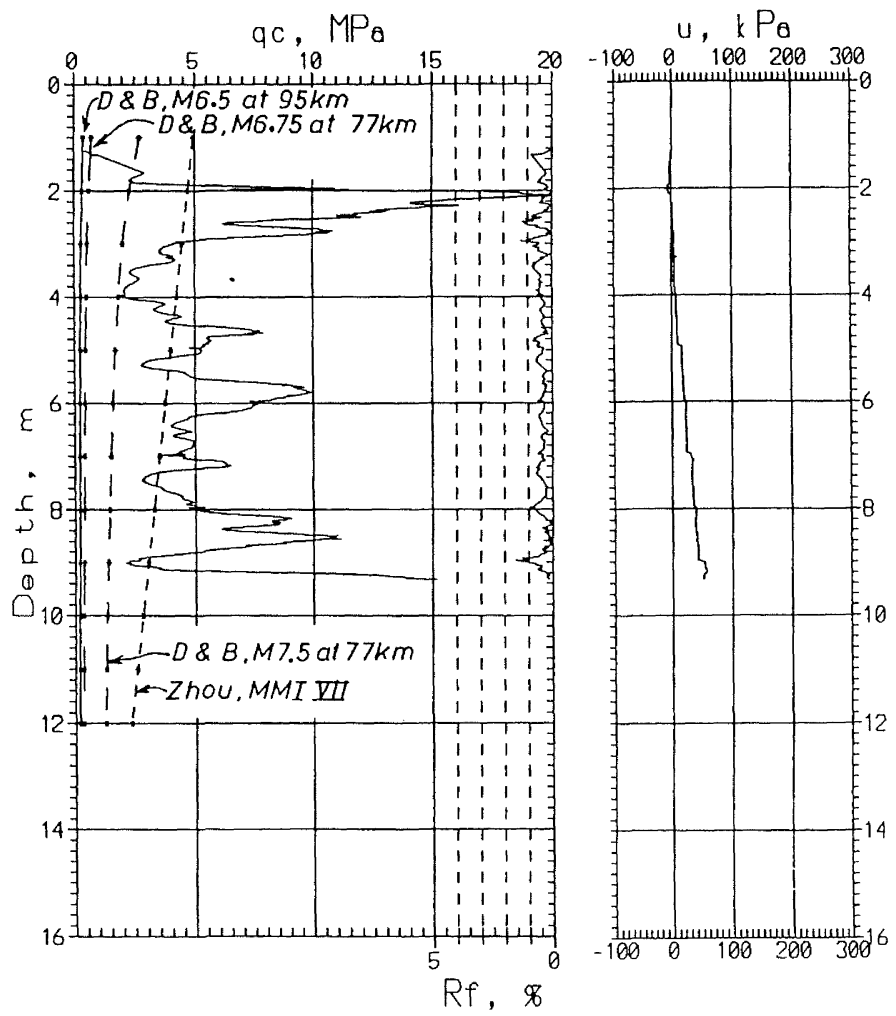

FIGURE 11 Piezocone results from Charles St No 2 site. 


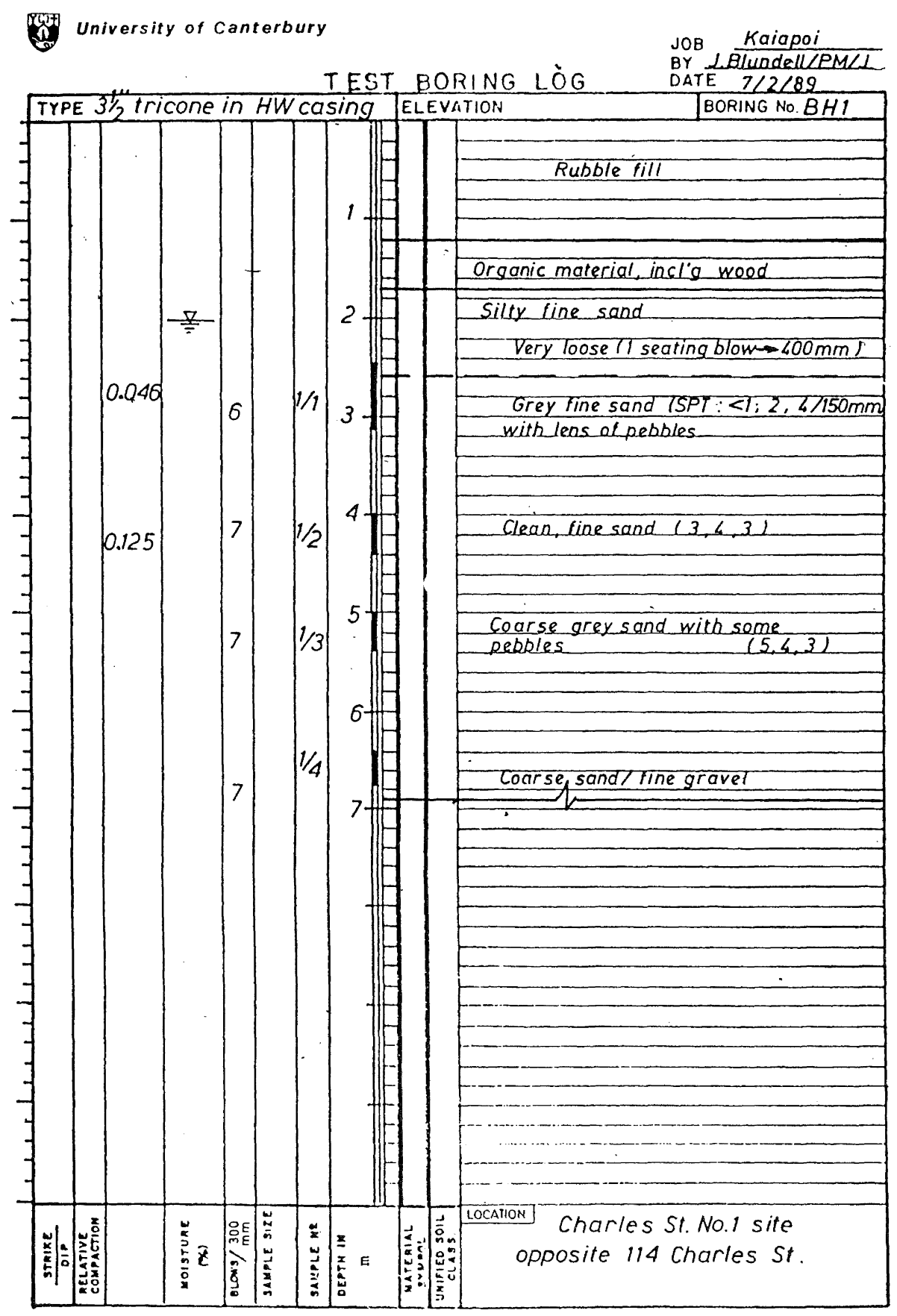

FIGURE 10 Log from rotary boring at Charles St No. 1 site.

\section{IMPLICATIONS FOR EARTHQUAKE PARAMETERS}

At the turn of the century, at the beginning of instrumental seismology, magnitude and epicentre estimates were necessarily crude due to the sparse distribution of instruments. For early New Zealand earthquakes, these parameters have been estimated by the Seismological Observatory usually from felt effects rather than instrumental measurements. For the Cheviot earthquake, the Observatory placed the epicentre about $77 \mathrm{~km}$ north of Kaiapoi with local magnitude in the range of 6 to 7.5. Dibble et al. [1980] reassessed magnitudes and epicentres of major historic earthquakes in the region, again using felt effects, and assigned $M_{L} 6.5$ with an epicentre $95 \mathrm{~km}$ from Kaiapoi, to the 1901 event. More recently, Dowrick and Smith [1990] have estimated magnitudes of a number of early New Zealand earthquakes using teleseismic records, and have found $M_{S} 6.9 \pm$ 0.2 for the Cheviot earthquake. Assuming that the Sewell St site liquefied in 1901, we can use the liquefaction potential model of Davis and Berrill [1983], in which earthquake strength is specified in terms of magnitude and distance, to examine these warious estimates for the 1901 earthquake.

Threshold values of $q_{c}$ from the model of Davis and Berrill [1983] are plotted in Figure 5 for various combinations of magnitude and distance. Determination of an appropriate "source distance" is one of the difficulties associated with attenuation models such as this. In calibrating their model, Davis and Berrill used epicentral distance when no information was available to make a better estimate using centre of energy release. The lowest threshold curve (M6.5 at $95 \mathrm{~km}$ ) 


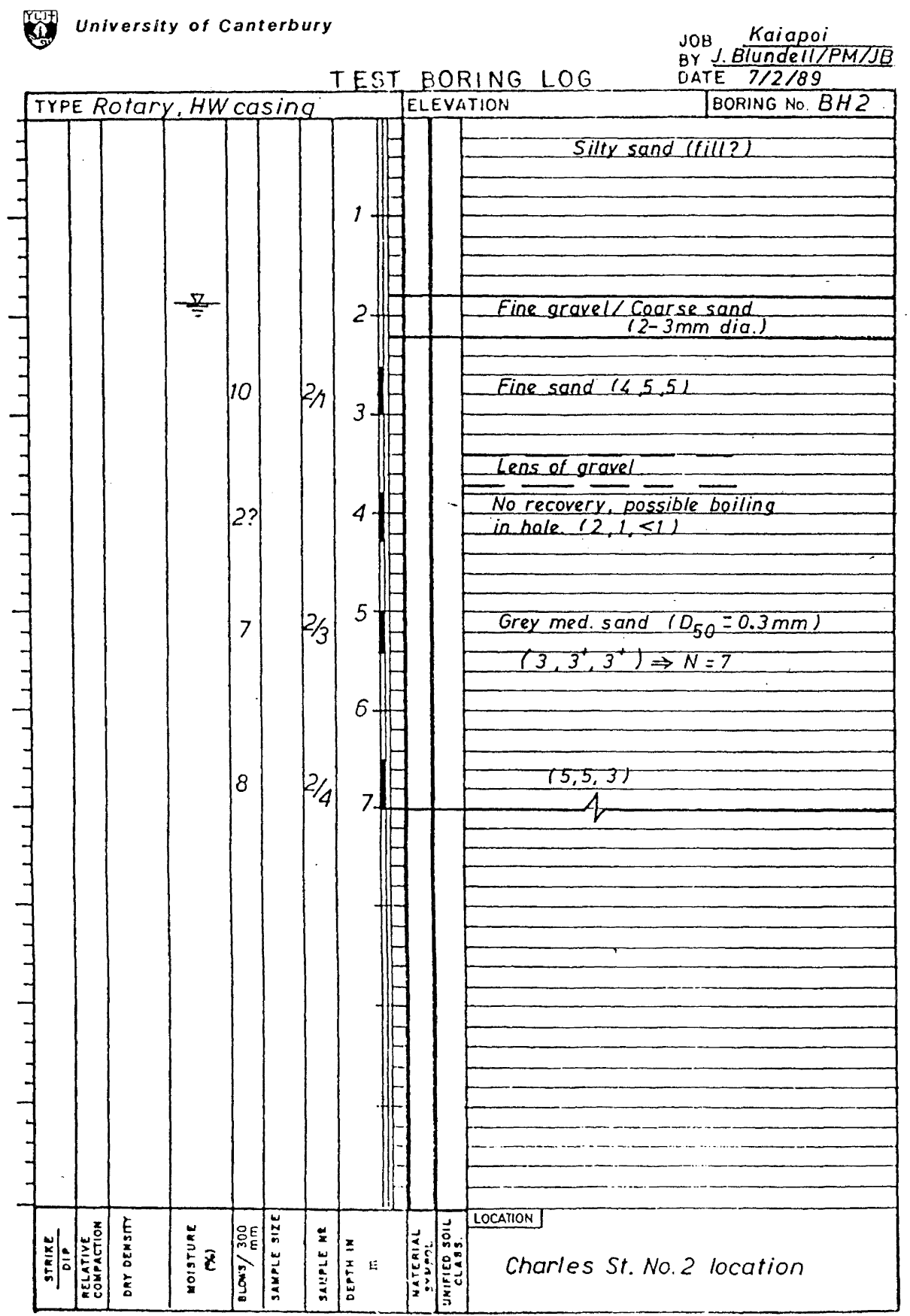

FIGURE 12 Log from rotary boring at Charles St No 2 site.

corresponds to the revised magnitude and epicentre of Dibble $e t$ al. [1980]; the next lowest curve (M6.75 at $77 \mathrm{~km}$ ) corresponds to the original epicentre and mean magnitude assigned by the Seismological Observatory. Under these conditions, the Davis and Berrill model does not predict liquefaction at the site, suggesting that either the model is somewhat unconservative, or that both sets of seismological parameters are incorrect. Since this model has been found to perform well at moderate and large epicentral distances [Liao et al., 1985] it is more likely that the Dibble $e t$ al. parameters are incorrect. Taking the upper end of the Observatory's magnitude estimate, $\mathrm{M}=7.5$, and their epicentre (at $77 \mathrm{~km}$ ), liquefaction is predicted in the loose cohesionless layer between 1.8 and $2.0 \mathrm{~m}$ and between 2.5 and $3.4 \mathrm{~m}$.
For liquefaction to occur in the layer at 2.5 to $3.4 \mathrm{~m}$ and taking the penetration resistance as $1.8 \mathrm{MPa}$ (near the smallest of the measured values in the layer), Dowrick and Smith's mean magnitude estimate of 6.9 requires a source distance of about 30 $\mathrm{km}$. This is not consistent with the observed damage, which was centred around the settlements of Cheviot and Parnassus [McKay, 1902], about 80 to $90 \mathrm{~km}$ from Kaiapoi. Even their upper estimate of $M_{S} 7.1$ requires a source distance of less than about $45 \mathrm{~km}$, which is still not consistent with a centre of damage around Cheviot. Thus it seems that Dowrick and Smith's magnitude estimate is on the low side, unless local and surface-wave magnitudes were significantly different for this event. 
Further information can be obtained from the criterion of Kuribayashi and Tatsuoka [1975] for distance to the farthest site of liquefaction. This criterion requires magnitudes 7.1 and 7.25 for liquefaction at the loosest of sites at distances of 77 and $95 \mathrm{~km}$ respectively. This result suggests that the magnitude was greater than 7, and again casts doubt on the revised epicentre estimate of Dibble et al. . However, it does lend some support to the upper end of the $M_{s}=6.9 \pm 0.2$ range of Dowrick and Smith [1990].

\section{REMARKS ON LIQUEFACTION POTENTIAL MODELS AND THE INTENSITY SCALE}

The discussion in the preceding section suggests that the Sewell St soils just liquefied and no more. However, for the MM intensity of VII assigned by Dibble et al. [1980], the Zhou model predicts liquefaction by a wide margin, throughout most of the profile. On the other hand, if we take the Seismological Observatory's estimate of MM 6 intensity at Kaiapoi, Zhou's model predicts no liquefaction. This illustrates both the coarse nature of the intensity scale itself, and its marked effect on the Zhou model. It also emphasises the danger of placing to much credence in individual intensity values. In general, the strength of the MM intensity scale is in bringing out regional trends. That, too, is its virtue when used as the seismic loading parameter in a liquefaction potential model, where it neatly overcomes the problem of choosing which source distance measure to use. Unfortunately, its benefit here is lost through the coarseness of the scale.

Threshold values of $\mathrm{q}_{\mathrm{c}}$ according to the Davis and Berrill model, for three sets magnitude and distance values, are plotted for the other three sites, too (Figures 6, 7 and 8). Without precise values of earthquake parameters, it is difficult to judge the performance of the model. Furthermore, its sensitivity to changes in seismological parameters emphasises the need for a large set of case histories to check or calibrate such models, and highlights the limitations of case studies where adequate seismological data is lacking.

\section{CPT-SPT RELATIONSHIP}

Since the CPT test is becoming more common, yet many design procedures in geotechnical engineering are based on SPT Nvalues, the relationship between CPT cone resistance $q_{c}$ and SPT $\mathrm{N}$ is of great interest. An old rule of thumb states that $\mathrm{q}_{\mathrm{c}}$ in bars equals $4 \mathrm{~N}$, in blows per $300 \mathrm{~mm}(1 \mathrm{bar} \simeq 100 \mathrm{kPa})$. This relationship was refined by Robertson and Campanella [1985] who found that it depended on grain size. They proposed the relationship shown in Figure 13, where $\mathrm{q}_{c} / \mathrm{N}$ is plotted as a function of mean grain size, $D_{50}$.

To check this relationship, we have plotted two results from Kaiapoi (Figure 13), together with several results obtained by Bienvenu [1988] at Buller sites. Only two points could be plotted for the Kaiapoi tests since it was only in two cases that sufficient material was recovered in the split-spoon sampler of the SPT for sieve analysis. The points plot around Robertson and Campanella's mean curve, but show somewhat more scatter than did their data points. Yet all the SPT tests were carried out very carefully, with Gemco trip hammers, by experienced 'drillers, in carefully advanced holes. At Kaiapoi, cased holes with bentonite drilling mud were employed, while in the Buller, hollow-stemmed augers were used. The augers were drilled in with the bottom plug removed. A head of water at or above ground level was maintained in the augers and the central tube cleared by bailing before each SPT test. Both techniques are common in New Zealand.

The results shown in Figure 13 generally support the Robertson and Campanella (and the $\mathrm{q}_{\mathrm{c}} / \mathrm{N}=4$ ) rule. But the large amount of scatter indicates that the relationship is not very precise, at least in the very loose, fine sand found at all of these sites. From these results there seems to be little advantage in using the Robertson and Campanella relationship rather than simpler $\mathrm{q}_{c} / \mathrm{N}$ $=4$ rule.

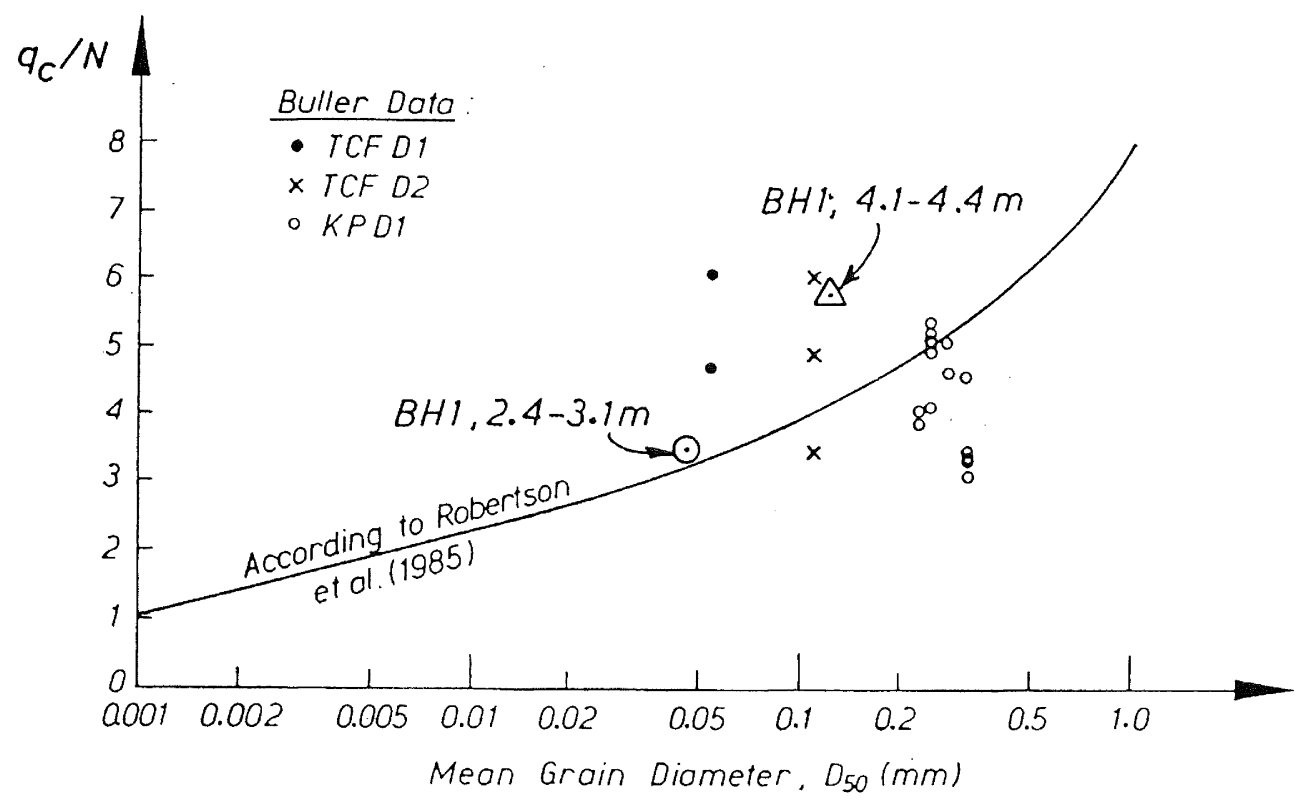

FIGURE 13 Ratios $q_{d} / N$ results from very loose silty sand strata at Kaiapoi and Buller sites, compared with Robertson and Campanella's (1985) curve. 


\section{CONCLUSIONS}

There is clear historical evidence for the occurrence of liquefaction in the north east section of Kaiapoi during the 1901 Cheviot earthquake. Piezocone probing and rotary boring was carried out at four sites east of Williams Street and adjacent to the north bank of the Kaiapoi river. Loose, silty fine sands with cone resistances ranging from 2 to $5 \mathrm{MPa}$ were found at all four sites. While it was not possible to pinpoint the 1901 sites precisely, the Sewell Street test site was almost certainly very close to, if not within, the Waites Market garden referred to in the 1901 newspaper reports and which was the principal site of liquefaction. The Sewell Street site was indeed the loosest of the four test sites, with cone resistances of about 2 to $3 \mathrm{MPa}$ throughout a layer extending from about $2 \mathrm{~m}$ down to a depth of about $6 \mathrm{~m}$, where denser coarse sands and fine gravels were encountered.

It is difficult to test liquefaction models against these results because precise seismological parameters for the earthquake are lacking. However, all four sites would liquefy according to the model of Zhou [1980] under the Modified Mercalli intensity of MM7 assigned by Dibble et al. [1980]. This does not provide unequivocal support for the Zhou model, however, since the reports of liquefaction were themselves used in assigning the intensity value. Dibble et al. estimated a magnitude of 6.5 at an epicentre about $95 \mathrm{~km}$ north of Kaiapoi. This epicentre is inconsistent with the formula of Kuribayashi and Tatsuoka [1975] for distance to the farthest site of liquefaction. Furthermore, with the Dibble et al. earthquake parameters, the model of Davis and Berrill [1983] predicts that none of the test sites should liquefy under these conditions. The earlier estimates by the Seismological Observatory, however, give a magnitude in the range 6 to 7.5 with a closer epicentre, at about $77 \mathrm{~km}$. With M7.5 at $77 \mathrm{~km}$, the Davis and Berrill model predicts liquefaction through most of the 2 to $6 \mathrm{~m}$ layer at Sewell Street; at the other three sites, it predicts that thin isolated layers may liquefy. These observations lend some weight to the Seismological Observatory's epicentre, with a magnitude near the upper end of the 6-7.5 range.

The value of $M_{s} 6.9 \pm 0.2$ of Dowrick and Smith [1990] appears to underestimate the local magnitude of the 1901 earthquake.

Even though it is not possible to make precise checks on prediction models with the penetration testing results, they do establish that there is a significant liquefaction hazard in this part of Kaiapoi. They also give us a set of sites with potentially liquefiable soils, of known properties spanning a range of densities, that can be checked following future earthquakes. At the two Charles Street sites at least, retesting to check for any modification of soil properties should be possible.

A comparison of Dutch cone penetrometer resistances and standard penetration test $\mathrm{N}$-values supports the old $\mathrm{q}_{\mathrm{c}}$ (bars) $/ \mathrm{N}$ $=4$ rule, but the data are quite scattered. In view of the large amount of scatter, use of the more refined rule of Robertson of Campanella, where $q_{c} / N$ is a function of $D_{50}$, does not seem warranted for soils as loose as these.

Finally, the scatter in the detailed features of the several penetration tests made at three of the sites should be of interest to geotechnical engineers, and warn against assuming that results from one or two probes or borings are exactly representative of even quite small sites.

\section{ACKNOWLEDGEMENTS}

This work forms part of a project to document New Zealand liquefaction sites and to study the behaviour of the piezocone in liquefiable soils, which has been supported by the NZ National Roads Board, EQC, the NZ Ministry of Energy, the University Grants Committee and by the French Ministry of Science and Technology. Their support is gratefully acknowledged.

Some of the 1989 tests were carried out by Mr J-L Pautre as part of his doctoral studies with the Institute of Mechanics, Grenoble, France. His contribution is gratefully acknowledged. Canterbury newspaper archives and the Christchurch Drainage Board records were searched by Mr Anthony Cuttriss, and his historian's skills are warmly appreciated. The co-operation of Kaiapoi landowners and of Mr Max Trumper of the former Kaiapoi Borough Council is also gratefully acknowledged. $\mathrm{Mr}$ John Webber, Dr Alan Hull and Dr Jarg Pettinga are thanked for their critical reading of the manuscript and their helpful suggestions.

\section{REFERENCES}

Berrill, J. B., P. C. Mulqueen, E. T. C. Ooi, and J.-L. Pautre. 1994. Liquefaction at Kaiapoi in the 1901 Cheviot, New Zealand Earthquake. Research Report No. 94/3, Dept of Civil Engineering, Univ. of Canterbury, New Zealand. 43 pp.

Bienvenu, V. C. 1988. Studies of Liquefaction in the 1929 Murchison and 1968 Inangahua, New Zealand Earthquakes. ME Thesis, University of Canterbury. $161 \mathrm{pp}$.

Brown, L. J. and J. H. Webber. 1992. Geology of the Christchurch Urban Area., Institute of Geological and Nuclear Sciences, Lower Hutt, NZ. 104 pp.

Davis, R. O. and J. B. Berrill. 1982. Energy Dissipation and Seismic Liquefaction in Sands. Intl. J. Earthq. Eng. and Struct. Dyn. 10:59-68.

Dibble, R. R., J. H. Ansell, J. B. Berrill. 1980. Report on a study of seismic risk for BP (NZ) Ltd sites at Woolston and Heathcote. Unpublished report to BP (NZ) Ltd.

Dowrick, D. J. and E. G. C Smith. 1990. Surface Wave Magnitudes of Some New Zealand Earthquakes 1901-1988. Bull. NZ. Nat. Soc. Earthq. Eng. 23:198-210.

Fairless, G. J. and J. B. Berrill. 1984. Liquefaction during Historic Earthquakes in New Zealand. Bull. NZ. Nat. Soc. Earthq. Eng. 17:280-291.

Kuribayashi, E. and F. Tatsuoka. 1975. Brief Review of Liquefaction during Earthquakes in Japan. Soils and Found. 15:81-92.

Liao, S. C., D. Veneziano and R. V. Whitman. 1988. Regression models for evaluating liquefaction probability. J. Geotechnical Eng. 114:389-411.

McKay, A. 1902. Report on the recent seismic disturbances within Cheviot County in North Canterbury and the Amuri district of Nelson, New Zealand (November and December 1901). Wellington, Government Printer. 88 pp. 
Mulqueen, P. C. 1988. Studies of Earthquake Induced Liquefaction at Kaiapoi New Zealand. Master of Engineering Report, University of Canterbury, Christchurch NZ.

Ooi, E. T. C. 1987. Investigation of Liquefaction in the Buller Region. Master of Engineering Report, University ${ }_{\mathbf{k}_{t}}$ of Canterbury, Christchurch NZ.

Robertson, P. K., R. G. Campanella and A. Wightman. 1983. SPT-CPT Correlations. Journal of the Geotechnical Engineering Division, ASCE, 109(GT11):1449-1459.

Reid, R. E. and R. H. Poynter. 1982. The Waimakariri River Improvement Scheme: 1982 Review. Unpublished report, North Canterbury Catchment Board, Christchurch, NZ.

Robertson, P. K. and R. G. Campanella. 1985. Liquefaction potential of sands using the CPT. J. Geotech. Eng., ASCE $111: 384-403$

Zhou, S. 1980. Evaluation of the liquefaction of sand by static cone penetration test. Proc. 7th World Conf. Earthq. Eng. Istanbul 3:156-162. 